Volume: 06, Issue: 05 "September-October 2020"

\title{
POSSIBILITIES OF USING SMALL WIND TURBINES FOR ELECTRICITY GENERATION IN AGRICULTURAL GREENHOUSES IN THE ISLAND OF CRETE, GREECE
}

\author{
John Vourdoubas \\ Consultant Engineer, 107B El. Venizelou Str., 73132, Chania, Crete, Greece \\ DOI: https://doi.org/10.51193/IJAER.2020.6508
}

\begin{abstract}
Renewable energies use in agricultural greenhouses results in the reduction of their environmental impacts. Aim of the current work is the investigation of using small wind turbines in greenhouses located in Crete, Greece for electricity generation. Crete hosts the majority of greenhouses in Greece which are mainly used for vegetable production. Use of wind turbines like other distributed electricity generation technologies has many economic and environmental benefits and they are highly desirable. The wind energy potential in various locations in Crete has been estimated as well as the electricity generated by small wind turbines from existing studies. In locations with high average annual wind speeds in Crete the cost of wind electricity is lower than the cost of grid electricity. In some of these locations there is a high concentration of greenhouses. Provided that net-metering regulations allow, additionally to solar electricity, generation of wind electricity use of small wind turbines in greenhouses with high annual electricity demand in Crete is economically profitable and environmentally attractive. Our results could help greenhouse growers as well as local authorities to promote the use of small wind turbines in Cretan greenhouses improving their environmental sustainability.
\end{abstract}

Keywords: Crete, distributed electricity generation, greenhouses, small wind turbines, renewable energies

\section{INTRODUCTION}

Electricity generation from renewable energy resources results in many economic and environmental benefits. Island of Crete, Greece has rich solar and wind energy resources as well as mild climate which favor the development of agricultural greenhouses. Almost $50 \%$ of the greenhouse area in Greece is located in the island of Crete focused in vegetable production while the most of them are plastic-covered without heating and with low annual energy consumption. 
Distributed electricity generation (DEG) using renewable energies (REs) is related with many environmental, technical and economic advantages. Small capacity wind turbines have been installed in rural and urban areas in stand-alone or grid connected systems worldwide. Possible applications for small wind turbines (SWT) are: electric power generation for households; electric power generation for industries and commerce; electric power generation for farms and isolated villages; use in boats; use in hybrid systems for electric power generation; water pumping; use in desalinization and purification systems; remote monitoring; educational systems; researches and telecommunication systems [1]. They are used alone or combined with solar photovoltaic (solar-PV) systems, batteries and diesel generators. Use of SWT systems covering part or all of the electricity requirements in greenhouses in Crete, Greece could be technically and economically feasible. In many locations dominated by greenhouses in Crete the wind energy potential is high resulting in high generation of wind electricity. Greenhouse growers in Crete could co-produce vegetables and electricity using SWT systems in their enterprises having an additional income due to electricity generation. Investigation of the possibility of co-producing vegetables and electricity using SWT in greenhouses is important for Cretan greenhouse growers since it could help them for achieving an additional income in their crops.

\section{LITERATURE SURVEY}

\subsection{Energy consumption in greenhouses}

Energy efficiency of greenhouses in the island of Crete, Greece has been studied [2]. The author stated that the cultivated area with greenhouses in Crete corresponds at $40.56 \%$ of the total greenhouse area in Greece. She also mentioned that electricity had a share at $12 \%$ in the overall energy consumption in Cretan greenhouses. Current situation of greenhouse vegetable production in Greece has been reported [3]. The authors mentioned that the total greenhouse area in Greece is around 5,600 ha while 96\% of the greenhouses used for vegetable production are plastic-covered. They also stated that only a small percentage, at 17\%, of greenhouse area used for vegetable production is heated in Greece. Energy consumption in a Cretan greenhouse used for flowers cultivation has been studied [4]. Indoor temperature in the greenhouse was kept around $20^{\circ} \mathrm{C}$ all over the year. Its annual electricity consumption was estimated at $14 \mathrm{KWh} / \mathrm{m}^{2}$ while its annual heat consumption at $214 \mathrm{KWh} / \mathrm{m}^{2}$. Energy input in greenhouse tomato production in Antalya, Turkey has been estimated [5]. The authors gathered data with face to face communication with growers. They calculated that the annual electricity input in greenhouses was $0.475 \mathrm{KWh} / \mathrm{m}^{2}$. Energy consumption in agricultural greenhouses used for vegetable production located in Antalya, Turkey has been calculated [6]. The authors calculated the energy consumption using data from questionnaires distributed in 101 greenhouse farms in 
International Journal of Agriculture and Environmental Research

ISSN: 2455-6939

Volume: 06, Issue: 05 "September-October 2020"

this territory. Operational total annual energy consumption was estimated at 6.6-7.2 $\mathrm{KWh} / \mathrm{m}^{2}$ and the annual electricity consumption at $0.35-0.47 \mathrm{KWh} / \mathrm{m}^{2}$. A hybrid energy system for achieving a nearly zero energy greenhouse has been evaluated [7]. The authors considered a greenhouse with a ground source heat pump providing heat and cooling in the greenhouse combined with grid connected solar-PV panels providing electricity. Annual energy requirements of the greenhouse for tomato, cucumber and lettuce production were estimated at $137.3 \mathrm{KWh} / \mathrm{m}^{2}$ to 165.3 KWh $/ \mathrm{m}^{2}$. They concluded that the proposed hybrid energy system could justify the idea of nearly zero energy greenhouses.

\subsection{Distributed electricity generation technologies}

The wind energy potential in Greece using a SWT at 2.5 KW and the HOMER software has been calculated [8]. The authors examined 69 locations in Greece estimating the energy production the electricity cost and the greenhouse gas emissions reduction. Their results indicated that wind electricity is cost competitive to grid electricity particularly in Southern Greek islands including Crete. Integration of small vertical axis wind turbines in buildings has been studied [9]. The author stated that small wind generators ( $200 \mathrm{~W}$ up to $10 \mathrm{KW}$ ) can be used in stand-alone or in grid connected buildings. He also mentioned that their use could assist in the achievement of zero energy buildings while they could have higher electricity generation than solar-PV systems. Various applications of SWT in residential buildings in Colorado, USA have been reported [10]. The author presented six case studies concerning SWT use. The case studies included on-grid and off-grid residential buildings with installations of SWT at 0.5-5 KW. Some of them were combined with solar-PV systems, batteries and back-up diesel generators. SWT applications in USA and Brazil have been reviewed [1]. The authors mentioned that promotion of SWT in Brazil is still a big challenge. They also stated that Brazil has to learn from USA's experience studying the policies elaborated there for the development of SWT applications. The performance of an innovative building-integrated wind turbine system utilizing the building skin for electricity generation has been studied [11]. The authors experimented with a prototype which accelerates the wind speed increasing the electricity generation. They also estimated that the wind turbine can cover $6.3 \%$ of the electricity requirements of the building. Building integrated wind turbines in Central Java, Indonesia have been investigated [12]. The authors focused in two regions having high wind energy resources. Performing computer simulations they concluded that wind turbine systems can generate significant amount of electricity covering part of the building's electricity needs. Environmental impacts of tomato production in Dutch greenhouses have been assessed [13]. The authors stated that use of co-generation of heat and power (CHP) systems in greenhouses results in selling the surplus electricity into the public grid reducing their environmental impacts due to energy use. They also mentioned that energy consumption in greenhouses varies significantly in various countries depending on climate 
International Journal of Agriculture and Environmental Research

ISSN: 2455-6939

Volume: 06, Issue: 05 "September-October 2020"

conditions and the technology used. The viability of DEG with biogas and solar-PVs in rural areas in Brazil has been investigated [14]. The authors mentioned that REs could be another source for electricity generation in Brazil where the most of electricity is generated by hydroelectric plants. Their estimation indicated that biogas produced from digestion of cattle's manure combined with solar-PV systems could be a viable option for electricity generation in isolated rural areas. The state of the art of the distributed CHP systems with small scale biomass plants has been reviewed [15]. The authors stated that efficient utilization of bio-fuels requires that the energy generation plants should be located nearby to the fuel source. They also mentioned that for micro-cogeneration and mini-cogeneration, micro-turbines, Sterling engines, fuel cells and internal combustion engines are the most promising technologies. A report on a pilot project in a rural area in the region of Parana, Brazil has been released [16]. The pilot project includes the creation of a rural grid using electricity generated with biogas produced by digestion of pig's manure. Integration of additional renewable energies, like solar energy, into the grid is foreseen for the future. Fuel cell technology for DEG has been overviewed [17]. The authors mentioned that fuel cell's technology is a new promising power generation technique which will play an important role in the future development of DEG. They also stated that all fuel cell types currently suffer from high capital costs. Technology, objectives and techniques of integrated DEG systems have been reviewed [18]. The authors presented different DEG technologies based on renewable and conventional energy sources and fuels. They concluded that optimal integration of DEG into the grid requires a holistic approach considering all parameters for achieving optimum system performance.

\subsection{Use of renewable energies for electricity generation in greenhouses}

Use of solar and wind energy in agriculture has been reported [19]. The authors mentioned that use of REs in agriculture and in greenhouses should be promoted. They also stated that in greenhouses $75 \%$ of the total energy is used for heating, $15 \%$ for electric applications and $10 \%$ for vehicle transportation. The feasibility of co-producing vegetables and electricity in greenhouses in Crete, Greece has been investigated [20]. The author stated that covering with semi-transparent solar-PV panels $15 \%$ of the roof in a greenhouse located in Crete, $16.8 \mathrm{KWh}$ per $\mathrm{m}^{2}$ of greenhouse surface could be generated. He also mentioned that the levelized cost of generated electricity is $0.082 € / \mathrm{KWh}$ while the annual decrease of $\mathrm{CO}_{2}$ emissions due to solar electricity production is $10.08 \mathrm{kgCO}_{2}$ per $\mathrm{m}^{2}$ of greenhouse surface. Wind turbine usage in Iran has been analyzed [21]. The authors mentioned that Firoozkouh region in Iran has a high wind energy density at $142.51 \mathrm{~W} / \mathrm{m}^{2}$ making generation of wind electricity attractive for covering part or all of the energy requirements in greenhouses. They also stated that the energy consumption rate in greenhouses was $11 \mathrm{KW} / \mathrm{ha}$. Integration of solar technology to modern greenhouses in China has been presented [22]. The authors mentioned that modern solar greenhouses in China 
International Journal of Agriculture and Environmental Research

ISSN: 2455-6939

Volume: 06, Issue: 05 "September-October 2020"

have many benefits in energy saving and pollution reduction. However they are characterized by poor heat preserving performance and the shadowing effect of solar-PV installations. They also stated that solar-PV greenhouses are attractive options having payback period less than 9 years. Use of solar, wind and geothermal energy in agriculture has been studied [23]. The authors mentioned that overcoming risks of future fossil fuels availability and their contribution to global warming requires the decoupling of the agricultural sector from fossil fuels. This can be achieved by increasing the energy efficiency and by using locally available REs for providing mechanical energy, heat and electricity in agriculture. Use of solar-PV systems in agricultural greenhouses optimizing both the electricity generation and the agricultural production has been studied [24]. The authors proposed the use of a mobile solar-PV system with variable shading adjusted to climatic conditions. They stated that changing the degree of shading inside a greenhouse based on the available solar radiation and on plants needs is feasible having many benefits. Advanced applications of solar energy in agricultural greenhouses have been reviewed [25]. The authors mentioned that solar energy can provide cheap and clean energy in greenhouses for heating, cooling, lighting and irrigation. They also stated that utilization of green energy for sustainable agriculture is a key issue in the current century.

Aim of the current work is the investigation of using small wind turbines in agricultural greenhouses in Crete, Greece.

After the literature survey the energy consumption and the current status of greenhouses in Crete are analyzed. After that the DEG technologies based on renewable energies and their current use in greenhouses is discussed. Next the solar and wind energy resources in the island of Crete and the possibility of using SWT in Cretan greenhouses are presented followed by the discussion of the results and the conclusions drawn.

\section{ENERGY CONSUMPTION IN AGRICULTURAL GREENHOUSES}

Agricultural greenhouses require energy for covering their energy needs in heating, cooling, lighting and operation of various electric devices and machinery. Operational energy consumption depends on the cultivated crop, the local climate and the type of greenhouse construction as well as the technology used. Therefore the annual energy consumption in greenhouses varies significantly [25], [22], [13]. Existing studies indicate that their requirements for heating and cooling are significantly higher than their needs for electricity [7], [4]. In various areas including the Mediterranean basin cultivation of various vegetables in traditional low-tech greenhouses does not require heating due to the mild local climate. The most common energy and fuels currently used are grid electricity (for lighting, cooling and operation of electric machinery) and heating oil or natural gas (for heating). Use of various renewable energy sources 
in greenhouses is limited so far. Energy consumption in greenhouses in various countries is presented in table 1 .

Table 3.1: Energy consumption in greenhouses

\begin{tabular}{|c|c|c|c|}
\hline $\begin{array}{l}\text { Author, } \\
\text { country }\end{array}$ & $\begin{array}{l}\text { Annual electricity } \\
\text { consumption } \\
\left(\mathrm{KWh} / \mathrm{m}^{2}\right)\end{array}$ & $\begin{array}{l}\text { Annual energy } \\
\text { consumption for } \\
\text { heating and cooling } \\
\left(\mathrm{KWh} / \mathrm{m}^{2}\right)\end{array}$ & $\begin{array}{l}\text { Total annual } \\
\text { energy } \\
\text { consumption } \\
\left(\mathrm{KWh} / \mathrm{m}^{2}\right)\end{array}$ \\
\hline $\begin{array}{l}\text { Hassanien, } 2016, \\
\text { various countries }\end{array}$ & & & $0.1-528$ \\
\hline Wang, 2017, China & & & $1.5-235.6$ \\
\hline $\begin{array}{l}\text { Vourdoubas, 2015, } \\
\text { Greece }\end{array}$ & 14 & & 328 \\
\hline $\begin{array}{l}\text { Yildirim, } \quad 2017, \\
\text { Turkey }\end{array}$ & 8.96 & $128.33-156.33$ & $137.26-165.29$ \\
\hline $\begin{array}{l}\text { Anton, } \quad 2012, \\
\text { Germany }\end{array}$ & & & 695 \\
\hline Anton, 2012, U.K. & & & 526 \\
\hline $\begin{array}{l}\text { Anton, 2012, } \\
\text { Mediterranean } \\
\text { countries }\end{array}$ & $3.3-39$ & & \\
\hline $\begin{array}{l}\text { Hatirli, } \quad 2005, \\
\text { Turkey }\end{array}$ & 0.475 & & \\
\hline $\begin{array}{l}\text { Canakci, } \quad 2006, \\
\text { Turkey }\end{array}$ & $0.35-0.47$ & & $6.6-7.8$ \\
\hline
\end{tabular}

Source: Various authors

\section{AGRICULTURAL GREENHOUSES IN CRETE}

The total area covered by greenhouses in Greece is estimated at about 5,600 ha [3] which corresponds approximately at $0.12 \%$ of the total cultivated area in the country. Around $96 \%$ of 
the greenhouses used for vegetables production in Greece are plastic covered. Island of Crete is the leading region in Greece regarding greenhouse production having almost half of the country's greenhouse area. The main vegetable crops produced in Greek greenhouses are tomato and cucumbers followed by peppers and eggplants. Due to the mild climate of the country and the fact that the heating cost is high, only $17 \%$ of the Greek greenhouses are heated while in Crete this percentage is lower. The cultivated area with greenhouses in Crete is estimated at 2,271 ha corresponding at $40.56 \%$ of the total cultivated area with greenhouses in the country [2].

\section{DISTRIBUTED GENERATION TECHNOLOGIES USING RENEWABLE ENERGIES WHICH COULD BE USED IN GREENHOUSES}

Various DEG technologies based on REs are currently used for electricity generation. Generated electricity could be used in greenhouses or it could be sold into the electric grid according to netmetering regulations. In the case of stand-alone greenhouses the energy generation system should be combined with electric batteries. These technologies include:

\subsection{Solar Photovoltaic systems}

Solar-PV systems are currently used for electricity generation. Depending on the intensity of the solar irradiance these systems are more or less attractive while they could generate part or all of the annual electricity requirements of the grid connected greenhouse. In many countries it is allowed, according to net-metering regulations, to store the electricity into the grid if the consumer does not need it when it is generated. They are intermittent energy generation systems while their cost has been substantially reduced during the last 15 years. Their average energy efficiency varies between $14-18 \%$. In many areas with high solar irradiance solar electricity is cheaper than electricity generated with conventional fuels.

\subsection{Wind turbines}

Wind turbines can be used for electricity generation. Necessary pre-condition for that is the high annual average wind speed at the site of the greenhouse. They can generate part or all the electricity requirements. Electricity generated can be sold into the electric grid, according to netmetering regulations, if it is not needed in the greenhouse when it is produced. Wind turbines require more maintenance than solar-PV systems and their applications in greenhouses worldwide are still limited.

\subsection{Solid biomass and biogas use}


Biogas, like natural gas, can be used for electricity generation in greenhouses while the coproduced heat can be also used for covering part of their heating needs. Biogas production by anaerobic digestion of organic wastes is currently technically and economically feasible and this fuel is currently used for energy generation or CHP. Additionally solid biomass could be used for CHP in greenhouses although its applications are limited so far. Various characteristics of distributed electricity generation technologies which could be used in greenhouses are presented in table 2.

Table 5.1: Characteristics of the abovementioned distributed electricity generation systems using renewable energies

\begin{tabular}{|l|l|l|l|l|}
\hline Technology used & $\begin{array}{l}\text { Total energy } \\
\text { efficiency }\end{array}$ & $\begin{array}{l}\mathrm{CO}_{2} \\
\text { emissions }\end{array}$ & $\begin{array}{l}\text { Existing } \\
\text { commercial } \\
\text { applications in } \\
\text { various sectors }\end{array}$ & $\begin{array}{l}\text { Existing } \\
\text { commercial } \\
\text { applications } \\
\text { in } \\
\text { greenhouses }\end{array}$ \\
\hline Photovoltaic panels & $\begin{array}{l}14-18 \% \\
\text { Wind turbines }\end{array}$ & $\begin{array}{l}\text { Low depending } \\
\text { on the average } \\
\text { annual wind } \\
\text { speed zero }\end{array}$ & Yes & Yes, few \\
\hline $\begin{array}{l}\text { Biogas or solid } \\
\text { biomass burning } \\
\text { and steam to power } \\
\text { engines }\end{array}$ & $\begin{array}{l}\text { 70-80\% (both } \\
\text { electricity and } \\
\text { heat } \\
\text { generation) }\end{array}$ & zero & Yes & No \\
\hline
\end{tabular}

Source: Vourdoubas, 2020

\section{APPLICATIONS OF DISTRIBUTED ELECTRICITY GENERATION TECHNOLOGIES BASED ON RENEWABLE ENERGIES IN GREENHOUSES}

Various DEG systems based on REs could be used in greenhouses reducing their conventional energy and fuel consumption and their carbon footprint. Their use is desirable since they increase their energy security and self-sufficiency while they result in many benefits for the electric grid regarding its stability. They provide an additional income for the farmer while they reduce the carbon footprint in agriculture utilizing local renewable energy sources instead of polluting fossil fuels. Taking into account that greenhouses require large amounts of heat energy for space 
heating the use of CHP systems based on biomass could cover a significant part of their heat and electricity requirements. For financing the required energy investments greenhouses could utilize new financial tools including third party financing and public private partnerships. An energy saving company (ESCO) could design, finance and implement the energy investments resulting in benefits both to the greenhouse owner and to the ESCO. The DEG systems which could be used in greenhouses depend on the availability of the energy source the maturity and the cost of the energy technologies and the possibility of achieving financial support by public subsidies. These sustainable energy systems include: solar-PV systems, small wind turbines and systems based in solid biomass and/or biogas burning.

The main factors which should be taken into account for the application of DEG technologies based on REs in greenhouses include:

1. Energy requirements (for heat, cooling and electricity) in the greenhouse,

2. Availability of the energy source (solar energy, wind energy, biomass) in the location of the greenhouse,

3. Legal regulations regarding the possibility of selling surplus electricity generated by the DEG system into the grid (net-metering regulations or/and feed-in tariffs),

4. Financial support offered by the government for the promotion of some sustainable energy technologies, and

5. Possibility of having local technical support in the installation, operation and maintenance of the energy system.

The DEG systems based on REs which could be used in greenhouses are presented in table 3 .

Table 6.1: Distributed generation technologies based on renewable energies which could be used in greenhouses

\begin{tabular}{|l|l|l|l|l|}
\hline $\begin{array}{l}\text { Distributed } \\
\text { generation } \\
\text { technology }\end{array}$ & $\begin{array}{l}\text { Energy/fuel } \\
\text { used }\end{array}$ & $\begin{array}{l}\text { Generated } \\
\text { energy }\end{array}$ & $\begin{array}{l}\text { Technology } \\
\text { efficiency }\end{array}$ & $\begin{array}{l}\text { Continuous/Inte } \\
\text { rmittent } \\
\text { generation }\end{array}$ \\
\hline Solar-PV & Solar & Electricity & $15-18 \%$ & Intermittent \\
\hline Wind turbine & Wind & Electricity & $\begin{array}{l}\text { Depends on the } \\
\text { wind speed }\end{array}$ & Intermittent \\
\hline $\begin{array}{l}\text { Solid } \\
\text { biomass/biogas }\end{array}$ & Biomass & $\begin{array}{l}\text { Electricity/he } \\
\text { at }\end{array}$ & $70-80 \%$ & Continuous \\
\hline
\end{tabular}


International Journal of Agriculture and Environmental Research

ISSN: 2455-6939

Volume: 06, Issue: 05 "September-October 2020"

\begin{tabular}{|l|l|l|l|}
\hline burning & & & \\
\hline
\end{tabular}

Source: Vourdoubas, 2020

\section{SOLAR AND WIND ENERGY RESOURCES IN CRETE}

Island of Crete has abundant solar and wind energy resources favoring their exploitation for the production of electricity and heat. During the previous twenty years many solar-PV systems as well as wind turbines/parks have been installed in the island generating a considerable part of its annual electricity consumption which is currently estimated at $14 \%$. The solar and wind energy resources in various locations in Crete are presented in table 5.1. Annual electricity generation by solar-PV systems in Crete is estimated approximately at 1,500 $\mathrm{KWh}$ per $\mathrm{KW}_{\text {peak. }}$ The capacity factor the annual hours of operation the generated electricity by a SWT at $2.5 \mathrm{KW}$ and the cost of electricity generated in the abovementioned locations, estimated by HOMER software, are presented below.

Table 7.1: Solar and wind energy resources in Crete

\begin{tabular}{|l|l|l|l|l|}
\hline Location & Latitude & Longitude & $\begin{array}{l}\text { Annual solar } \\
\text { irradiance }- \\
\text { inclination 30 } \\
\left(\mathrm{KWh} / \mathrm{m}^{2}\right)^{\circ}\end{array}$ & $\begin{array}{l}\text { Annual } \\
\text { average wind } \\
\text { speed }(\mathrm{m} / \mathrm{sec})^{2}\end{array}$ \\
\hline Chania & $35^{\circ} 29^{\prime}$ & 2407 & 1,738 & 3.517 \\
\hline Ierapetra & 3500 & 2544 & 1,882 & 4.725 \\
\hline Iraklio & 3520 & 2511 & 1,744 & 4.783 \\
\hline Kissamos & 3550 & 2370 & & 5.214 \\
\hline Rethymno & 3521 & 2431 & 1,691 & 3.900 \\
\hline Sitia & 3512 & 2606 & 1,743 & 5.271 \\
\hline Souda & 3533 & 2407 & 1,731 & 3.683 \\
\hline Timpaki & 3500 & 2446 & 1,847 & 5.378 \\
\hline
\end{tabular}

${ }^{1}$ Source: Kagarakis, 1987, ${ }^{2}$ Source: Fantidis et al, 2013

The capacity factor and the annual hours of operation of a SWT in various locations in Crete is presented in table 5.2 
International Journal of Agriculture and Environmental Research

ISSN: 2455-6939

Volume: 06, Issue: 05 "September-October 2020"

Table 7.2: Capacity factor and hours of operation of a small wind turbine in various locations in Crete $^{1}$

\begin{tabular}{|l|l|l|}
\hline Location & Capacity factor & Annual hours of operation \\
\hline Chania & 0.134 & 6,753 \\
\hline Ierapetra & 0.278 & 7,638 \\
\hline Iraklio & 0.289 & 7,609 \\
\hline Kissamos & 0.341 & 7,864 \\
\hline Rethymno & 0.177 & 7,125 \\
\hline Sitia & 0.348 & 7,885 \\
\hline Souda & 0.149 & 7,009 \\
\hline Timpaki & 0.363 & 7,922 \\
\hline
\end{tabular}

${ }^{1}$ Source: Fantidis et al, 2013

The annual electricity generation and the cost of electricity generated by a SWT in various locations in Crete are presented in table 5.3

Table 7.3: Annual electricity generation and cost of electricity generated by a small wind turbine in various locations in Crete $^{1}$

\begin{tabular}{|l|l|l|l|}
\hline Location & $\begin{array}{l}\text { Annual electricity } \\
\text { generation } \\
(\mathrm{KWh} / \text { year })\end{array}$ & $\begin{array}{l}\text { Annual electricity } \\
\text { generation } \\
\left(\mathrm{KWh} / \mathrm{KW}_{\text {el }} \text { year }\right)\end{array}$ & $\begin{array}{l}\text { Cost of electricity } \\
(€ / \mathrm{KWh})\end{array}$ \\
\hline Chania & 2,940 & 1,176 & 0.124 \\
\hline Ierapetra & 6,097 & 2,439 & 0.060 \\
\hline Iraklio & 6,338 & 2,535 & 0.058 \\
\hline Kissamos & 7,467 & 2,987 & 0.049 \\
\hline Rethymno & 3,884 & 1,554 & 0.094 \\
\hline Sitia & 7,619 & 3,048 & 0.048 \\
\hline Souda & 3,269 & 1,308 & 0.112 \\
\hline Timpaki & 7,960 & 3,185 & 0.046 \\
\hline
\end{tabular}

1 Source: Fantidis et al, 2013

\section{POSSIBILITIES OF USING SMALL SIZE WIND TURBINES IN CRETAN GREENHOUSES}

Depending on the average annual wind speed in a location in Crete the cost of electricity generated by a SWT could be low (table 5.3). This is true particularly in areas with many greenhouses like Timpaki, Ierapetra and Kissamos where the average annual wind speed is high. 
International Journal of Agriculture and Environmental Research

ISSN: 2455-6939

Volume: 06, Issue: 05 "September-October 2020"

In these areas the installation of SWT as well as solar-PV systems covering the annual electricity needs of greenhouses could be profitable. In the past wind mills, utilizing the rich local wind energy resources, were used for underwater pumping and irrigation in agricultural crops in Crete. However the current use of SWT in various crops or in greenhouses worldwide is very limited [23]. Installation of SWT in grid connected greenhouses requires the use of net-metering regulations allowing the storage of the excess electricity, when it is not needed in the greenhouse, into the grid instead of storing it in costly electric batteries. Other prerequisites for the installation of SWT in Cretan greenhouses are a) the high mean annual wind velocity at the location, b) the low cost of the SWT in $€ / \mathrm{KW}, \mathrm{c})$ the low cost of generated electricity in $€ / \mathrm{KWh}$ which must be below the cost of grid electricity and d) requirements for having an electric battery combined with the SWT. Additionally, the greenhouse grower could have environmental benefits, reducing its carbon footprint, due to electricity generation by solar or wind energy. In the case of unheated greenhouses and in-situ generation of solar or wind electricity growers could zero their carbon footprint due to energy use. SWT and hybrid solar-wind electricity generation systems could be installed by local cooperatives in areas dominated by greenhouses like the abovementioned locations in Crete. In that case agricultural cooperatives could also operate as energy cooperatives/communities achieving economic and environmental benefits to their members. Taking into account that the cultivated area of greenhouses in Crete is 2,271 ha [2], [3] and assuming that their annual electricity consumption is $1 \mathrm{KWh} / \mathrm{m}^{2}$ the annual electricity consumption in all Cretan greenhouses is calculated at 22,710 MWh. Assuming that the $\mathrm{CO}_{2}$ emissions during electricity generation are $0.6 \mathrm{tnCO} / \mathrm{MWh}$ the total annual $\mathrm{CO}_{2}$ emissions due to electricity use in Cretan greenhouses are estimated at $13,626 \mathrm{tnCO}_{2}$. The current cost of grid electricity in greenhouses in Greece is approximately $0.07 € / \mathrm{KWh}$. Therefore the cost of electricity generated by wind turbines in some locations dominated by greenhouses in Crete (table 5.3) is lower than the current cost of grid electricity.

\section{DISCUSSION}

Our results indicate that the use of SWT systems in agricultural greenhouses in Crete, Greece could be profitable if the local wind energy resources are rich. The results are useful indicating that DEG systems based on wind energy could be useful in agriculture generating additional incomes and improving the sustainability of the primary sector. However net metering regulations should allow the use of SWT systems like solar-PV systems in greenhouses in Crete. Use of SWT systems does not imply a high profit for small size unheated greenhouses with low annual energy consumption. However it could be attractive for agricultural cooperatives which could install SWT systems generating collectively electricity covering the annual electricity needs of their members. It is recommended that existing net-metering regulations in Greece should be changed allowing the use of wind electricity like solar electricity. Additionally it is 
International Journal of Agriculture and Environmental Research

ISSN: 2455-6939

Volume: 06, Issue: 05 "September-October 2020"

proposed the encouragement of agricultural cooperatives in greenhouse dominated locations in Crete to create energy communities installing local DEG systems utilizing the rich wind and solar energy resources of Crete. This could help in covering the energy needs of their members increasing at the same time the environmental sustainability in agriculture.

\section{CONCLUSIONS}

The possibility of installing SWT systems in agricultural greenhouses in Crete, Greece has been investigated. Our results indicate that island of Crete, Greece has abundant solar and wind energy resources making attractive the use of DEG systems based on REs. In various locations in the island with high mean annual wind speeds the cost of wind electricity is competitive with the current price of grid electricity. Region of Crete has almost the half of the country's greenhouses. The most of them are plastic covered without heating and with low energy consumption used mainly for vegetables production including tomato, cucumbers, peppers and eggplants. In these locations, rich in wind energy resources, the installation of SWT in greenhouses could generate part or all of their annual electricity requirements allowing to growers to have a complementary income from electricity generation increasing also their environmental sustainability. Greenhouses using wind electricity could be stand-alone or grid connected. In the first case electric batteries are needed for wind electricity storage while in the second case net-metering regulations should allow the use of SWT systems apart from solar-PV systems. In small scale village-type Cretan greenhouses with low energy consumption the potential economic benefit from the use of SWT systems is rather small. However agricultural cooperatives should create energy communities generating collectively wind electricity for covering the energy needs of their members achieving electricity self-sufficiency, economic benefits and reduction of their environmental footprint. Further research should be focused in the implementation of a case study regarding the economic and environmental benefits of small, middle and large scale greenhouses in Crete using SWT systems for covering part or all of their annual electricity needs.

\section{REFERENCES}

[1] C.C. Moreira Chagas, M.G. Pereira, L. Pinguelli Rosa, N. Fidelis la Silva, M.A. Vasconcelos Freitas, \& J.D. Hunt, "From Megawatts to Kilowatts: A review of small wind turbine applications, Lessons from US to Brazil", Sustainability, 12, 2760, 2020. doi:10.3390/su12072760

[2] G. Dascalaki, "The efficiency of greenhouses on the island of Crete regarding energy and economics", M.Sc. thesis, Mediterranean Agronomic Institute of Chania, 2012.

[3] D. Savvas, A. Ropokis, G. Ntatsi \& C. Kittas, "Current situation of greenhouse vegetable production in Greece", Acta Horticulturae, Vol. 1142, pp. 443-448, 2016. 
International Journal of Agriculture and Environmental Research

ISSN: 2455-6939

Volume: 06, Issue: 05 "September-October 2020"

DOI:

10.17660/ActaHortic.2016.1142.67

https://doi.org/10.17660/ActaHortic.2016.1142.67

[4] J. Vourdoubas, "Overview of heating greenhouses with renewable energy sources, A case study in Crete, Greece", Journal of Agriculture and Environmental Sciences, Vol. 4, No. 1, pp. 70-76, 2015. DOI: 10.15640/jaes.v4n1a9

[5] S.A. Hatirli, B. Ozkan \& C. Fert, "Energy inputs and crop yield relationship in greenhouse tomato production", Renewable Energy, Vol. 31, No. 4, pp. 427-438, 2006. doi:10.1016/j.renene.2005.04.007

[6] M. Canakci \& I. Akinci, "Energy use pattern analysis of greenhouse vegetable production", Energy, pp. 1243-1256, 2006. doi:10.1016/j.energy.2005.05.021

[7] N. Yildirim \& L. Bilir, "Evaluation of a hybrid system for a nearly zero energy greenhouse", Energy Conversion and Management, Vol.148, pp. 1278-1290, 2017. http://dx.doi.org/10.1016/j.enconman.2017.06.068

[8] J.G. Fantidis, D.V. Bandekas, N. Vordos, \& S. Karachalios, "Wind energy potential in Greece using a small wind turbine", Recent Advances in Energy, Environment and Development, Cambridge, January 30 - February 1, 2013, USA. Retrieved at 20/10/2020 from

https://www.researchgate.net/publication/257929879_Wind_Energy_Potential_in_Greece Using_a_Small_Wind_Turbine

[9] M. Casini, "Small vertical axis wind turbines for energy efficiency in buildings", Journal of Clean Energy Technologies, Vol. 4, No. 1, pp. 56-65, 2016. DOI: 10.7763/JOCET.2016.V4.254

[10] J. Green, "Small wind turbine applications: current practice in Colorado", in Colorado Renewable Energy Conference, Winter park, Colorado, September 10-12, 1999, National Renewable Energy Laboratory.

[11] J. Park, H-J. Jung, S-W. Lee \& J. Park, "A new building-integrated wind turbine system utilizing the building", Energies, Vol. 8, pp. 11846-11870, 2015. doi:10.3390/en81011846

[12] D. Perwita Sari \& W. Banar Kusumaningrum, "A technical review of building integrated wind turbine system and a sample simulation model in Central Java, Indonesia", Energy Procedia, Vol. 47, pp. 29-36, 2014. doi: 10.1016/j.egypro.2014.01.193 
International Journal of Agriculture and Environmental Research

ISSN: 2455-6939

Volume: 06, Issue: 05 "September-October 2020"

[13] A. Anton, M. Torrellas, J.I. Montero, M. Ruijs, P. Verneulen \& C. Stanghellini, "Environmental impact assessment of Dutch tomato crop production in a Venlo glasshouse", Proceedings of $28^{\text {th }}$ International Horticultural Congress on greenhouse 2010 and soilless cultivation, Editor: N. Castilla, Acta Horticulturae, Vol. 927, pp. 781-791, 2012. DOI: 10.17660/ActaHortic.2012.927.97

[14] E.R. Bernardes, \& J.R. Camacho, "Viability of distributed generation with biogas and photovoltaic in an isolated system", International Conference on Renewable Energies and Power, April, 10-12, 2019, Tenerife, Spain.

[15] M. Salomon, T. Savola, M. Kirjavainen, A.R. Martin, \& C-J. Fogelholm, "Distributed combined heat and power generation with small scale biomass plants - State of the art review", Second International Symposium on Distributed Generation, Power Systems and Market Aspects, October, 2-4, 2002, Stockholm, Sweden.

[16] "Distributed generation using biogas in a micro-grid in Western region of Parana, Brazil", Biogas in Society, IEA Bio-Energy Task 37, February 2019. Retrieved at 27/10/2020 from https://www.ieabioenergy.com/wpcontent/uploads/2019/03/IEA_Brazil-Solar-Biogas_Case-Story.pdf

[17] X. Huang, Z. Zhang \& J. Jiang, "Fuel cell technology for distributed generation: An overview", IEEE ISIE 2006, 9-12 July 2006. Montreal, Quebec, Canada, pp: 1613-1618. DOI: 10.1109/ISIE.2006.295713

[18] P. Paliwal, N.P. Patidar, \& R.K. Nema, "Planning of grid integrated distributed generators: A review of technology, objectives and techniques", Renewable and Sustainable Energy Reviews, Vol. 40, pp. 557-570, 2014. http://dx.doi.org/10.1016/j.rser.2014.07.200

[19] Y.D.J. Acosta-Silva, I. Torres-Pacheco, Y. Matsumoto, M. Toledano-Ayala, G.M. SotoZarazua, O. Zelaya-Angel \& A. Mendez-Lopez, "Applications of solar and wind energy in agriculture: A review", Science Progress, Vol.102, No.2, pp. 127-140, 2019. DOI: $10.1177 / 0036850419832696$

[20] J. Vourdoubas, "Co-production of vegetables and electricity in agricultural greenhouses in Crete, Greece. Is it feasible?", Journal of Agriculture and Life Sciences, Vol. 7, No. 1, pp. 1-8, 2020. doi:10.30845/jals.v7n1p1

[21] R. Shahbazi, S. Kouravand \& R. Hassan-Beygi, "Analysis of wind turbine usage in greenhouses: wind resource assessment, distributed generation of electricity and 
environmental protection, Energy Sources, Part A: Recovery, Utilization and Environmental Effects", 2019. DOI: 10.1080/15567036.2019.1677810

[22] T. Wang, G. Wu, J. Chen, P. Cui, Z. Chen, Y. Yan, Y. Zhang, M. Li, D. Niu, B. Li \& H. Chen, "Integration of solar technology to modern greenhouse in China: Current Status, challenges and prospect", Renewable and Sustainable Energy Reviews, Vol. 70, pp. 1178-1188, 2017. http://dx.doi.org/10.1016/j.rser.2016.12.020

[23] J. Bundschuh, C. Guangnan, B. Tomaszewska, N. Ghaffour, S. Shahbaz Mushtaq, I. Hamawand, K. Reardon-Smith, T. Maraseni, T. Banhazi Hacene, G. Mattheus, \& D.L. Mahmoudi, "Solar, wind and geothermal energy applications in agriculture: back to the future?", in Geothermal, Wind and Solar Energy Applications in Agriculture and Aquaculture, 2017, ed. Jochen Bundschuh, Guangnan Chen, D. Chandrasekharam and Janusz Piechocki, Routledge Handbooks. Retrieved at 20/10/2020 from https://www.researchgate.net/publication/318671733_Solar_wind_and_geothermal_energ y_applications_in_agriculture_back_to_the_future

[24] S. Moretti \& A. Marucci, "A photovoltaic greenhouse with variable shading for the optimization of agricultural and energy production", Energies, Vol. 12, pp. 2589, 2019. doi:10.3390/en12132589

[25] R.H.E. Hassanien, M. Li \& W.D. Lin, "Advanced applications of solar energy in agricultural greenhouses", Renewable and Sustainable Energy Reviews, Vol. 54, pp. 989-1001, 2016. http://dx.doi.org/10.1016/j.rser.2015.10.095 